\title{
Determination of Some Heavy Metals in water of the Southern Region of Lake Manzala, Egypt
}

\author{
Wael H. Hegazy ${ }^{1}$, Mohamed A. Hamed ${ }^{2}$, M. E. S. Toufeek ${ }^{2}$ and \\ Bazada K. A. Mabrouk ${ }^{2}$ \\ 1- Department of Chemistry, Faculty of Science, Suez University, Egypt \\ 2- National Institute of Oceanography and Fisheries, Egypt
}

\section{ABSTRACT}

Lake Manzala is the largest Nile Delta, coastal ecosystem in Egypt. To examine of the pollution in the lake, the levels of some heavy metals ( $\mathrm{Fe}, \mathrm{Mn}, \mathrm{Zn}, \mathrm{Cu}, \mathrm{Pb}, \mathrm{Ni}$, $\mathrm{Cd}$ and $\mathrm{Co}$ ) were assessed in water samples collected from twelve stations covering the southern region of the lake area, seasonally from the spring 2014 to winter 2015. The lake has undergone substantial recent changes particularly over the last 30 years due to increasing the inflows of drainage water, land reclamation and increasing loads of pollutants.

The obtained results confirmed that, industrial, agricultural and domestic sewage drained into the lake from the main drains has a considerable impact on the water quality characteristics of the lake. The concentration of heavy metals varied in a wide range; increased in the southern region and decreased towards north eastern part of the lake. Heavy metals discharged into the lake causes a momentous environmental problem.

Keywords: Lake Manzala, heavy metals, pollution, plankton, fish.

\section{INTRODUCTION}

Lake Manzala is the largest of the Nile Delta coastal brackish ecosystem. Geographically, it is located between longitudes $31^{\circ} 45^{\prime}$ and $32^{\circ} 22^{\prime} \mathrm{E}$ and latitudes $31^{\circ} 00^{\prime}$ and $31^{\circ} 35^{\prime} \mathrm{N}$. The lake is bordered by Mediterranean Sea to the North and the North-East, Suez Canal to the East, Dakahlia and Sharkia Provinces to the South and Damietta Branch of the Nile to the West (Hossen and Negm, 2016).

The lake is connected with the Mediterranean Sea by five outlets permitting exchange the water and biota between the lake and the sea (Rashad and Abdel-Azeem 2010). These outlets are El-Gamil, El-Boughdady and the new El-Gamil (Elewa et al., 2007). The lake is also connected to the Suez Canal at El-Qabouti; a few kilometers to the South of Port Said, and connected with the Damietta branch of the Nile through the El-Inaniya, Souffara and El-Ratma Canals (Sallam and Elsayed, 2015).

Lake Manzala is shrinking everyday due to input from human activities (ElSaharty, 2014). Several decades ago the surface area of the lake was $1698 \mathrm{~km}^{2}$ and reduced by 1988 to $770 \mathrm{~km}^{2}$ (Saeed and Shaker, 2008) due to continuous land reclamation projects.

The southern region of the lake receives about 7500 million cubic meters of untreated industrial, domestic and agricultural drainage water. This amount of water was reduced to about 4000 million cubic meters after construction of El-Salam Canal (Abdel-Baky, et al., 1998).

Lake Manzala is linked to six drains through the southern and western shores (Donia and Hussein, 2004), these drains discharge into the lake and affect its water quality (Mustafa et al., 2015). So, the southern part of the lake water maintained high 
heavy metals levels which exceed the allowable maximum concentration reported by Word Health Organization, which might cause a public health problem (Abdel-Satar, 2001).

The direction of water flow is from the Lake to the sea and vice versa and a pollutant coming from drains affects the whole area of the Lake (El-Naggar et al., 2016).

The contamination by heavy metals in the aquatic environments has drawn particular attentions due to their toxicity, persistence and biological accumulation (Zahran et al., 2015). Such pollutions can negatively impact human health and ecosystems through a range of accumulatory processes within the food chain (Dar et al., 2015). Once they enter the food chain, ultimately humans may accumulate heavy metals from these diets (Barakat, 2011). Fish is at the top of the aquatic food chain, and during its life can accumulate large amounts of toxic elements, when heavy metals accumulate in fish, they are finally transferred to other animals within the food chain (Nwabunike, 2016). Also, fish are considered as a key species in trophic levels that concentrate large amounts of metals (Mahboob, et al., 2014).

The high values of heavy metals would limit drainage water reuse or increase the mixing ratio between fresh and drainage waters (Nasr et al., 2014). Existence of heavy metals either at high or low concentrations must be effectively removed from the drains (Misheloff, 2010).

Lake Manzala attracts attention of many scientists because of its important economic aspects. Several investigations have been carried out concerning its ecosystem. These studies dealt with different environmental aspects of the lake including geological aspects, hydrological regime, physico-chemical properties, bacterial indices, phytoplankton composition, benthic invertebrates, fishery status and water quality and pollution of the lake (El-Wakeel and Wahby, 1970; Dowidar and Hamza, 1983; Abdel-Mouti, 1985; Abdel-Mouti and Dowidar, 1988; Khalil and ElAwamri, 1988; Khalil and Bayoumi, 1988; Khalil, 1990; El-Ghobashy, 1990; ElSabrouti and Mahmoud 1990; Said, 1992; El-Bokhty, 1996; Hussein 1997, AbdelSatar, (1998, 2001 and 2009); Frihy et al., 1998; Abdel-Baky and Zyadah, 1998; Dewidar and Khedr, 2001; Fathi et al. 2001; Flower, 2001; Lotfy, 2001 and 2007; Abdalla, 2003; Fathi and Abdelzahar, 2003; Abbassy et al., 2003; El-Enany, 2004; Mabrouk, 2004; Gad, 2005; Yacoub et al. 2005; Ali. 2008; El-Refaie, 2010; Hamed, et al., 2013; Mehanna, et al., 2014; Orabi and Osman, 2015; Zahran, et al., 2015 and EL-Shafei, 2016).

The main objective of this research is to determine the levels of some heavy metals ( $\mathrm{Fe}, \mathrm{Mn}, \mathrm{Zn}, \mathrm{Ni}, \mathrm{Cu}, \mathrm{Pb}, \mathrm{Cd}$ and $\mathrm{Co}$ ) in the lake water because of their health implications to human populations consuming fishes from the lake.

\section{MATERIALS AND METHODS}

\section{Collection of samples}

Samples of water were collected seasonally during the period from spring 2014 to winter 2015 from the selected station in polyethylene bottles. The bottles were previously rinsed several times with lake water before collection. The entire samples were kept in cleaned stoppered plastic bottles of two-liter capacity and have been acidified using $5 \mathrm{ml}$ concentrated nitric acid at collection. 
Table 1: Selected stations in Lake Manzala

\begin{tabular}{|l|l|}
\hline No. of station & Stations \\
\hline I & El-Serw Drain \\
\hline II & El-Serw D.P. \\
\hline III & Faraskour Drain \\
\hline IV & Faraskour D.P. \\
\hline V & Hadous Drain \\
\hline VI & Hadous D.P. \\
\hline VII & Old Bahar El-Bakar Drain \\
\hline VIII & Old Bahar El-Bakar Drain D.P. \\
\hline IX & New Bahar El-Bakar Drain \\
\hline X & New Bahar El-Bakar Drain D.P. \\
\hline XI & El-Genka \\
\hline XII & El-Boom \\
\hline XIII & El-Matariya \\
\hline
\end{tabular}

\section{Methodology:}

For heavy metals analysis water samples were digested by adding $10 \mathrm{ml}$ of nitric acid to $500 \mathrm{ml}$ of water sample in a beaker and boiled slowly on a hot plate till the lowest volume, nearly $15-20 \mathrm{ml}$ before precipitation occurs, until complete digestion. Beaker walls were washed carefully with distilled water then the digested samples were transferred to a $100 \mathrm{ml}$ volumetric flask and completed to the mark with deionized distilled water. A portion of this solution was used for the determination of heavy metals.

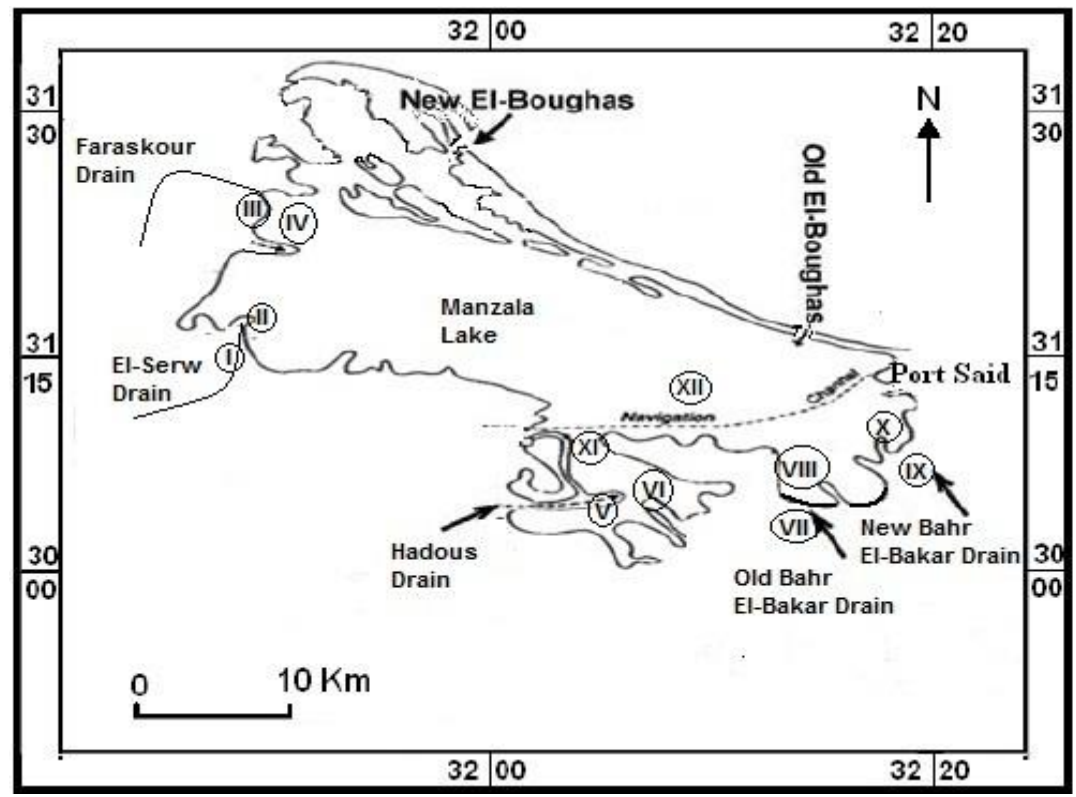

Fig. 1: A map of Lake Manzala showing the drains and collecting stations

\section{RESULTS}

\section{Heavy Metals}

The contamination by heavy metals in the aquatic environments has drawn particular attentions due to their toxicity, persistence and biological accumulation (Zahran, et al., 2015). 
Iron contents in the lake water fluctuated in a relatively wide range (Fig. 2). Furthermore, the results showed slight increase of Fe during spring and summer than other seasons. The values of $\mathrm{Fe}$ at different stations were found to be in the ranges of 0.00-18.48, 3.06-33.09, 0.00-24.45 and 2.04-35.26 $\mu \mathrm{g} / \mathrm{l}$ during autumn, winter, spring and summer, respectively. The highest levels of the iron $(35.26 \mu \mathrm{g} / \mathrm{l})$ were found during summer in front of the New Bahar El-Bakar Drain. The lowest values occurred during autumn at El-Boom station away from the southern region which contains drains.

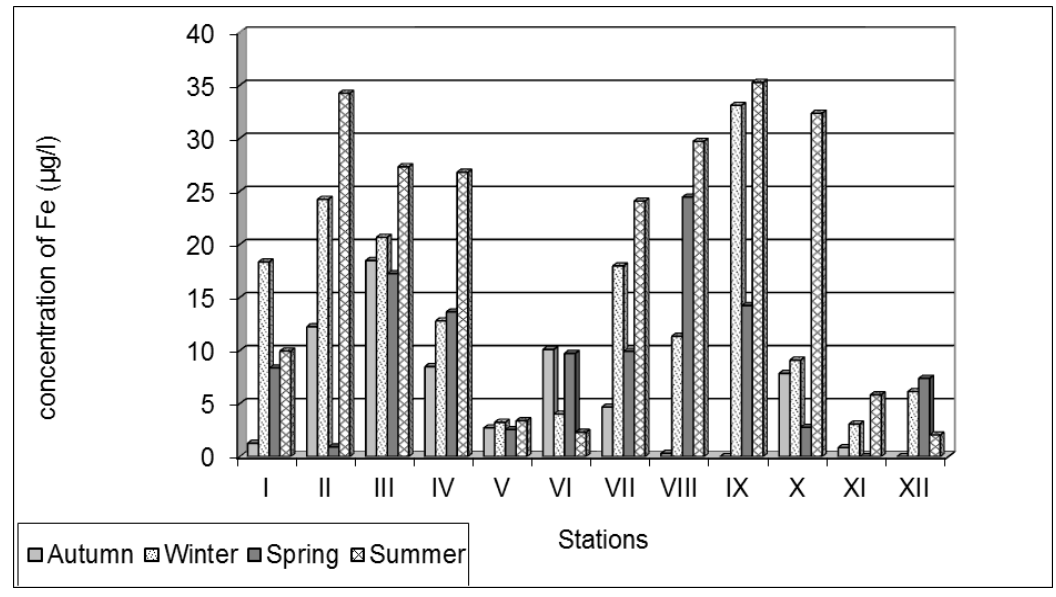

Fig. 2: Seasonal variation of iron concentration ( $\mu \mathrm{g} / \mathrm{l})$ in Lake Manzala during 2014-2015.

Concerning the average annual values, the least value was $2.43 \mathrm{mg} / \mathrm{l}$ which recorded at El-Genka station, while the highest one was recorded at Faraskour Drain which was $20.92 \mathrm{mg} / \mathrm{l}$.

On the other hand, manganese values exhibited a similar distribution trend as iron. The values of Manganese ranged between 0.256-1.727, 0.837-3.19, 0.198-3.7 and $0.745-6.091 \mu \mathrm{g} / 1$ during autumn, winter, spring and summer respectively. The minimum value of manganese was recorded at El-Boom Station during winter $(0.108$ $\mu \mathrm{g} / \mathrm{L})$, but the maximum value was recorded at El-Serw Drain Station during summer (Fig. 3).

Concerning the average annual values of $\mathrm{Mn}$, the least value was $0.21 \mathrm{mg} / \mathrm{l}$, which recorded at El-Boom station, while the highest one was recorded at El-Serw Drain which was $2.46 \mathrm{mg} / \mathrm{l}$.

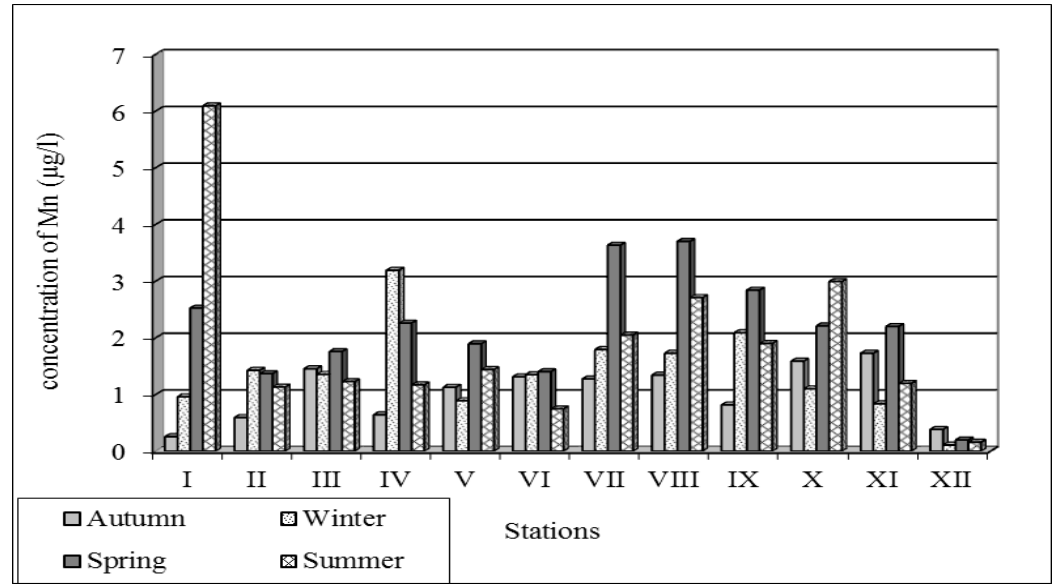

Fig. 3: Seasonal variation of manganese concentration $(\mu \mathrm{g} / \mathrm{l})$ in different stations of Lake Manzala during 2014-2015. 
The values of zinc were varied in the range between $0.487-3.929,1.865-3.818$, 1.811-3.042 and 1.887-4.726 $\mu \mathrm{g} / 1$ during autumn, winter, spring and summer respectively.

The maximum value $(4.726 \mu \mathrm{g} / \mathrm{l})$ was observed at Old Bahar El-Bakar Drain during summer season, while the minimum one was recorded at New Bahar El-Bakar Drain $(0.487 \mu \mathrm{g} / \mathrm{l})$ during autumn (Fig. 4).

The values of copper were varied in the range between $0.00-0.030,0.0-0.103$, $0.00-0.031$ and $0.00-0.163 \mu \mathrm{g} / \mathrm{l}$ during autumn, winter, spring and summer respectively. The levels of copper showed a similar trend as Fe and Mn, where its values increased during summer.

Results revealed that, the maximum value of copper was recorded at Old Bahar El-Bakar D.P. during summer $(0.163 \mu \mathrm{g} / \mathrm{l})$. While the minimum value was recorded at Hadous D.P. during autumn $(0.004 \mu \mathrm{g} / \mathrm{l})$ beside the depletion of copper which present in many stations. (Fig. 5).

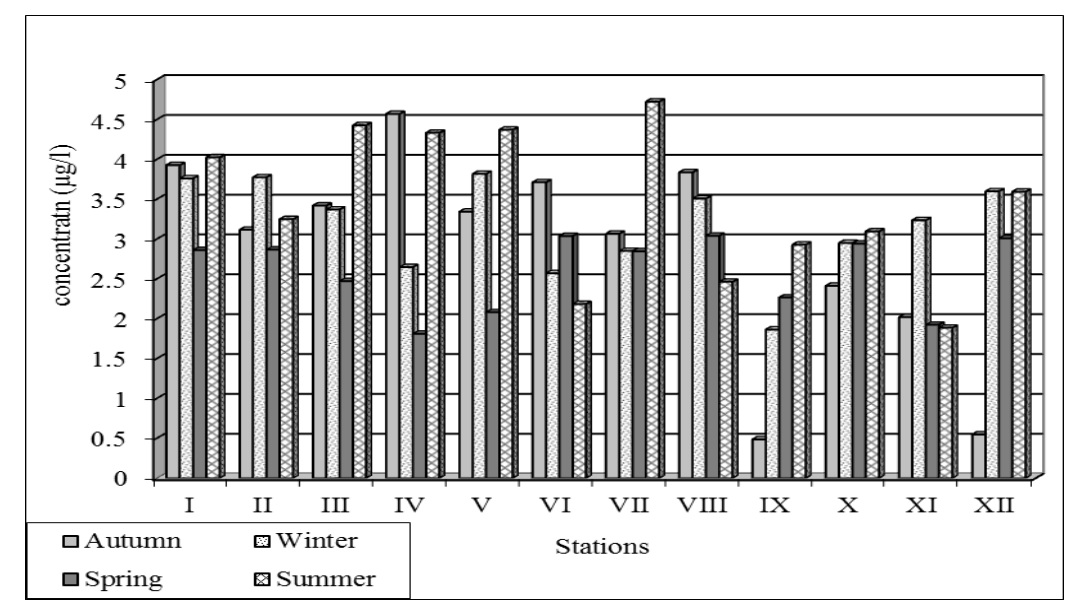

Fig. 4: Seasonal variation of zinc concentration $(\mu \mathrm{g} / \mathrm{l}))$ in different stations of Lake Manzala during 2014-2015.

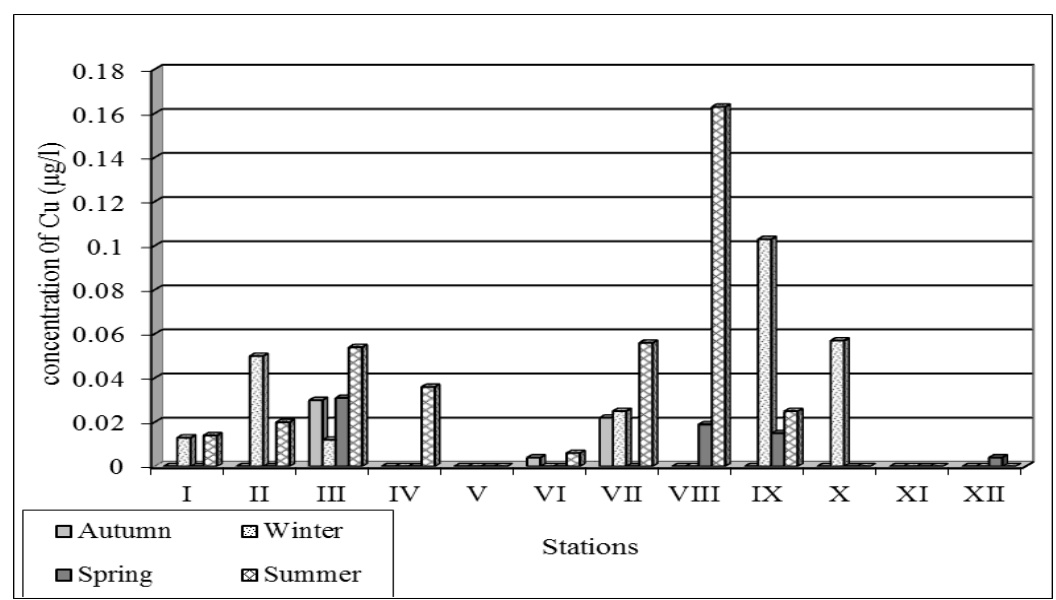

Fig. 5: Seasonal variation of copper concentration $(\mu \mathrm{g} / \mathrm{l}))$ in different stations of Lake Manzala during 2014-2015.

The values of lead were varied in the range between $0.00-0.023,0.0-0.418,0.00$ 0.064 and $0.00-0.364 \mu \mathrm{g} / \mathrm{l}$ during autumn, winter, spring and summer respectively. Results revealed that, the maximum value of lead was recorded at New Bahar ElBakar D.P. during winter $(0.364 \mu \mathrm{g} / 1)$. The minimum one was recorded at Faraskour 
D.P. during summer $(0.012 \mu \mathrm{g} / \mathrm{l})$. Beside the depletion of lead which was recorded in many stations (Fig. 6).

The values of cadmium were varied in the range between $0.00-0.014,0.0-0.001$ and $0.00-0.028 \mu \mathrm{g} / \mathrm{l}$ during autumn, winter, and summer respectively. While in spring, a total depletion of cadmium was recorded in all investigated samples (Fig. 7).

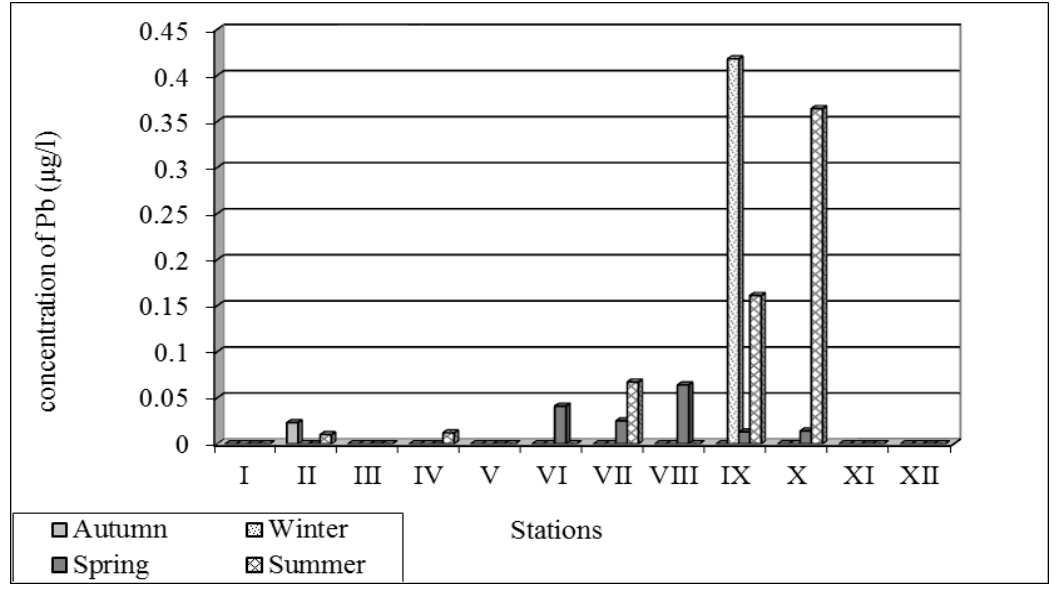

Fig. 6: Seasonal variation of lead concentration $(\mu \mathrm{g} / \mathrm{l})$ in different stations of Lake Manzala during 2014-2015.

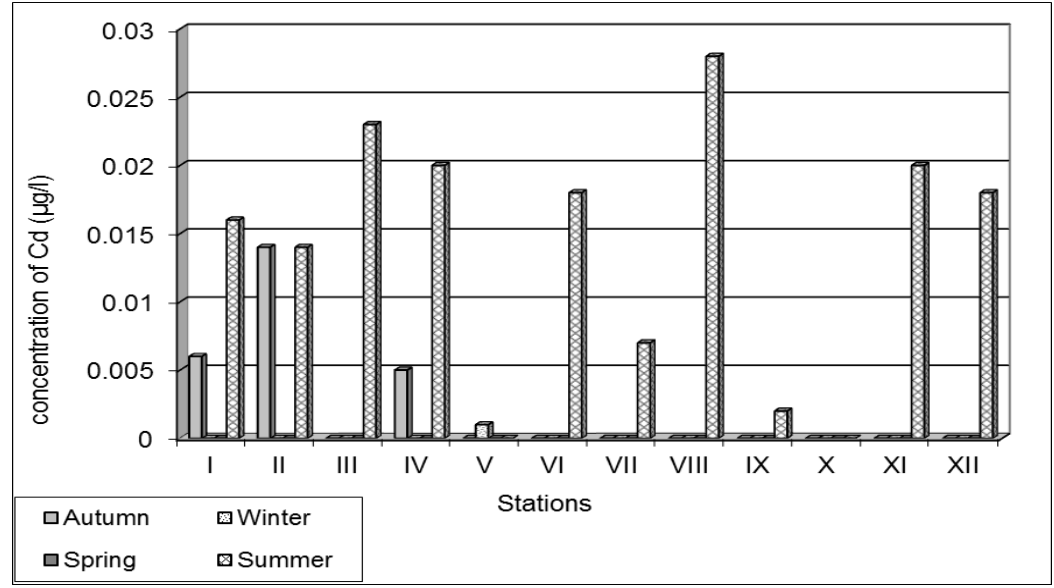

Fig. 7: Seasonal variation of cadmium concentration $(\mu \mathrm{g} / \mathrm{l})$ in different stations of Lake Manzala during 2014-2015.

Results revealed that, the maximum value of cadmium was recorded at Old Bahar El-Bakar D.P. during summer $(0.028 \mu \mathrm{g} / 1)$. The minimum one was recorded at Hadous Drain during winter season $(0.01 \mu \mathrm{g} / \mathrm{l})$. The depletion of cadmium which was recorded in many stations.

The values of nickel were varied in the range between $0.00-0.084,0.0-0.085$, $0.0-0.105$ and $0.00-0.201 \mu \mathrm{g} / 1$ during autumn, winter, spring and summer respectively (Fig. 8). Results revealed that, the maximum value of nickel was recorded at New Bahar El-Bakar Drain during summer $(0.201 \mu \mathrm{g} / \mathrm{l})$.

The values of cobalt were varied in the range between 0.00-0.051, and $0.00-$ $0.126 \mu \mathrm{g} / 1$ during winter and summer respectively. During autumn and spring a total depletion of cobalt was recorded in all investigated samples. 
Results revealed that the maximum value of cobalt was recorded at New Bahar El-Bakar D.P. during summer $(0.126 \mu \mathrm{g} / \mathrm{l})$, while, the minimum value was recorded at New Bahar El-Bakar D.P. during winter $(0.02 \mu \mathrm{g} / 1)$. Depletion of cadmium which was recorded in many stations (Fig. 9).

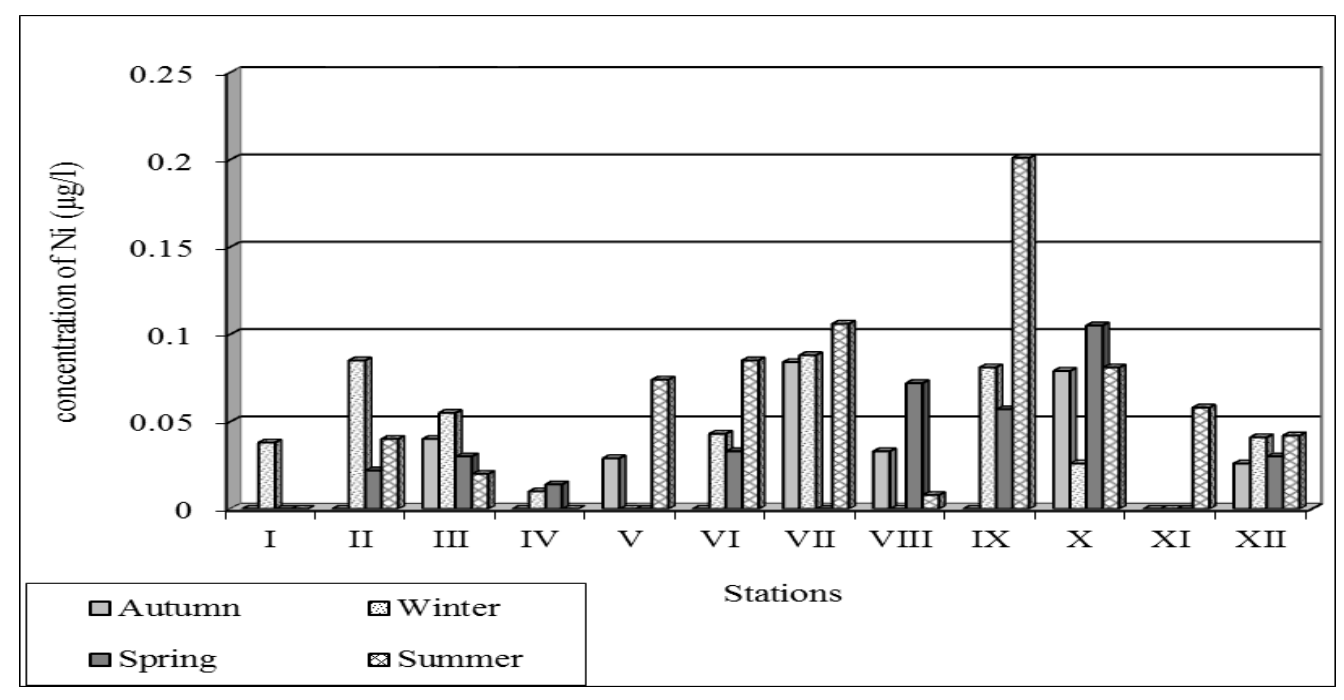

Fig. 8: Seasonal variation of nickel concentration $(\mu \mathrm{g} / \mathrm{l})$ in different stations of Lake Manzala during 2014-2015.

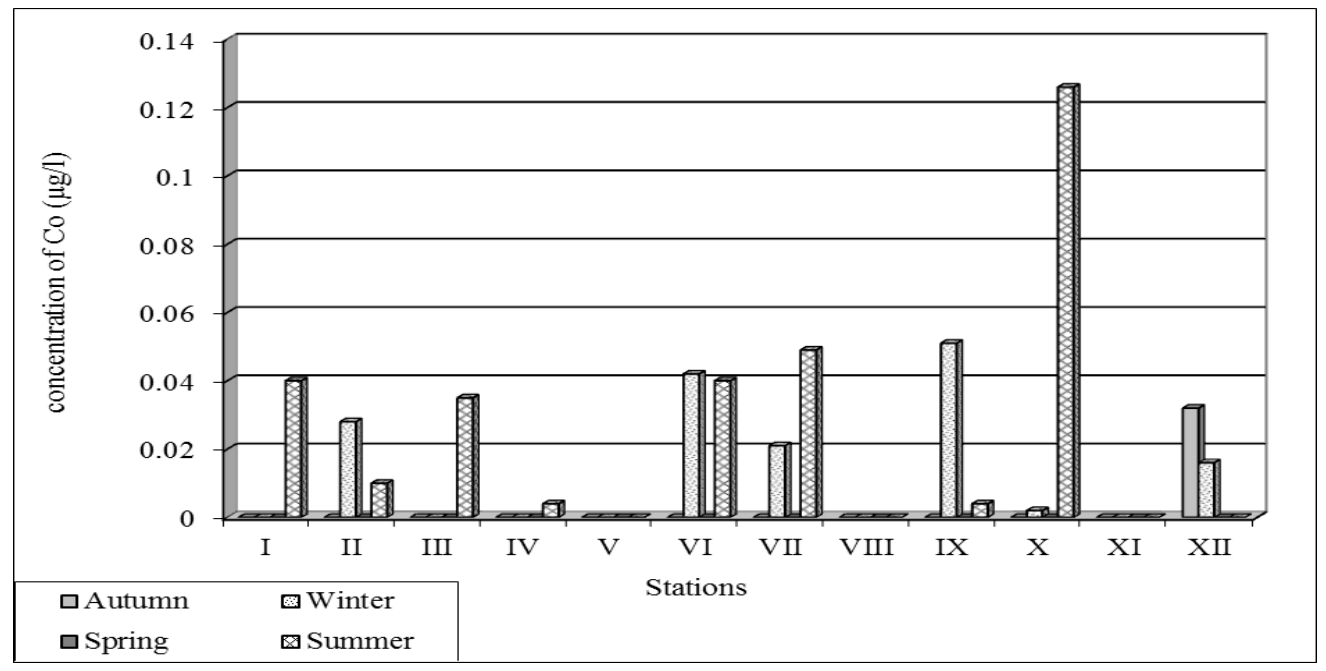

Fig. 9: Seasonal variation of cobalt concentration $(\mu \mathrm{g} / 1)$ in different stations of Lake Manzala during 2014-2015.

\section{DISCUSSION}

Trace metals have a great ecological significance in aquatic ecosystem due to their toxicity and accumulation behavior. In general, the heavy metals; lead, copper, cadmium, zinc, cobalt and nickel, produce their toxicity by forming complexes or "ligands" with organic compounds (El-badry, 2016).

The increasing of Fe during spring and summer than other seasons is due to the elevation of temperature, which decreases the assimilation rate of $\mathrm{Fe}$ by aquatic organisms especially macrophytes (Berg et al., 1995). 
The occurrence of lowest values at El-Boom station which is away from the southern region may be attributed to the direct precipitation of iron and clarity of water at this station.

These results are in agreement with those obtained by Ghallab (2000), El-Enany (2004), Rasheed (2011), Bahnasawy et al., 2011, Nwabueze \& Oghenevwairhe, 2012 and Saad et al., 2013.

The increasing of Mn during hot seasons than cold ones is mainly attributed to the mobilization of manganese from the sediment to the overlaying water due to the decomposition of organic debris by microbial activity. The high evaporation rate and the raising of water temperature and air during hot seasons causing increasing of manganese concentrations, that comes with the industrial and sewage effluents which drain to the water body (Goher, 1998).

It is clear that the concentration of zinc decreases in autumn, which may be attributed to the adsorption of zinc on iron colloids and precipitated to sediments (Maria et al. 2000 and El-Sayed, 2011).

The highest values of zinc concentrations were recorded at Bahr El-Bakar drain which carries higher amount of domestic, industrial and agricultural wastes. This agreed with Rasheed, (2011).

The increasing of $\mathrm{Cu}$ values during summer is mainly attributed to the precipitation of copper to the sediment as $\mathrm{CuS}$ under elevation of temperature (Hutchinson, 1957). The presence of maximum value of copper at Old Bahar ElBakar D.P. during summer $(0.163 \mu \mathrm{g} / \mathrm{l})$, is attributed the highly amount of industrial discharge in this drain.

The minimum value of copper was recorded at Hadous D.P. during autumn $(0.004 \mu \mathrm{g} / \mathrm{l})$. Depletion of copper was recorded in many stations. This may be attributed to the uptake of phytoplankton and other aquatic plants. Copper concentrations of the present study are lower than those obtained by Aboul-Ezz and Abdel-Razek (1991), El-Enany(2004) and Rasheed (2011).

The maximum value of lead was recorded at the New Bahar El-Bakar D.P. during winter. This may be due to the highly amount of industrial discharge in this drain, from the effect of effluent of Bahr El-Bakar drain which carry higher amount of domestic, industrial and agricultural wastes. This result agreed with Abdo, (2002), ElSayed (2011) and Rasheed (2011).

The presence of the maximum value of cadmium at the Old Bahar El-Bakar D.P. during summer, may be due to the highly amount of industrial discharge in this drain, or due to the effect of effluent of Bahr El-Bakar drain which carry higher amount of domestic, industrial and agricultural wastes. This result agreed with Rasheed (2011).

The decrease in cadmium concentrations during cold period may be attributed to the uptake of cadmium by aquatic plants, invertebrates accumulated during this period (Touffek, 1993).

The maximum value of cobalt was recorded at the New Bahar El-Bakar D.P. during summer. While, the minimum value was recorded at New Bahar El-Bakar D.P. during winter $(0.02 \mu \mathrm{g} / \mathrm{l})$. Depletion of cadmium which was recorded in many stations (Fig. 9). This result agreed with Nagpal (2004) and Zahran et al.,( 2015).

Mehanna et al. (2014) declared that, the annual variation of heavy metals (Fe, $\mathrm{Cu}, \mathrm{Zn}, \mathrm{Pb}, \mathrm{Mn}, \mathrm{Cd}$ and $\mathrm{Hg}$ ) concentration in the lake water was; Iron concentration ranged from 0.32 to $1.71 \mathrm{ppm}$, copper concentration ranged from 0.01 to $0.68 \mathrm{ppm}$, zinc concentration ranged from 0.017 to $0.66 \mathrm{ppm}$, lead concentration ranged from 
0.001 to $0.30 \mathrm{ppm}$, manganese concentration ranged 0.001 to $1.09 \mathrm{ppm}$ and cadmium concentration ranged from 0.0001 to $0.06 \mathrm{ppm}$.

El-badry 2016 found that the highest concentrations of $\mathrm{Cd}, \mathrm{Pb}, \mathrm{Ni}$ and $\mathrm{Zn}$ in water were observed in the eastern portion of the lake where industrial zone of Port Said country whiles the lowest values were recorded at the western portion of the lake. Highest $\mathrm{Cu}$ and $\mathrm{Co}$ values were recorded in the western area towards el-Serw agricultural drain. The relative order of abundance of the potentially toxic metals in the lake's water is; $\mathrm{Pb}>\mathrm{Cu}>\mathrm{Zn}>\mathrm{Cd}$.

\section{CONCLUSIONS}

Generally, the distribution of heavy metals in Lake Manzala revealed that the highest concentrations of heavy metals were observed in the northeastern and the southern parts of the lake nearby drains. This attributed to industrial, agricultural and municipal wastes coming through the drains especially Bahr El-Bakar drain and the industrial wastes coming from Port Said area.

A monitoring program should be set up to control the pollution in this vital important ecosystem and mange it healthy fish production.

\section{REFERENCES}

Abbassy, M.S.; Ibrahim, H.Z. and Abdel-Kader, H.M. (2003). Persistent Organochlorine Pollutants in the Aquatic Ecosystem of Lake Manzala, Egypt, Bull. Environ. Contam. Toxicol., 70: 1158-1164.

Abdalla, M.A.H. (2003). Study of natural radioactivity, environmental isotopes and hydrochemistry of some northern lakes in Egypt. PhD Thesis, Faculty of Science, Cairo University, Egypt.

Abdel-Baky, T.E. and Zyadah, M.A. (1998). Effect of accumulation of copper, cadmium and zinc on some biological parameters of some marine fishes from the northern region of Lake Manzala, Egypt. J. Egypt. Ger. Soc. Zool., 27(B): 119.

Abdel-Baky, T.E.; Hagras, A.E.; Hassan, S.H. and Zyadah, M.A. (1998). Environmental impact assessment of pollution in Lake Manzalah. 1Distribution of some heavy metals in water and sediment. J. Egypt. Ger. Soc. Zool., 26 (B): 25- 38.

Abdel-Mouti M.A.R. and Dowidar, N.M. (1988). Trace elements status in surficial sediments of Manzala Lake, Egypt. Bull. Nat. Inst. Ocean. and Fish., ARE, 14: 183- 202.

Abdel-Mouti, M.A.R. (1985). Studies on the chemistry of Manzala lake waters, Egypt. PhD Thesis, Faculty of Science, Alexandria University, Egypt.

Abdel-Satar, A.M. and Geneid, Y.A. (2009). Evaluation of heavy metal status in Ecosystem of lake Manzalah, Egypt. J. Environ. Res., 3(3): 194-204.

Abdel-Satar, A.M. (1998). Environmental studies on the impact of the drains effluent upon the southern sector of Lake Manzala, Egypt. J Aquat. Biol. and Fish, 5: 1730 .

Abdel-Satar, A.M. (2001). Environmental studies on the impact of the drains effluent upon the southern sector of Lake Manzala, Egypt, Egypt. J. Aquat. Biol. and Fish., 5(3):17-30. 
Abdo, M.H. (2002). Environmental studies on Rosetta branch and some chemical applications at the area extend from El-Kanater El-Khyria to Kafr-El-Zyat city. Ph. D Thesis, Fac. of Sci. Ain Shams Univ., Cairo, Egypt.

Aboul-Ezz, A.S. and Abdel-Razak, S.A. (1991). Heavy metals in Tilapia nilotica and in the water of Lake Manzala. Egypt. Journal Appl. Sci., 6(6):37-52.

Ali, M.M.H. (2008). Assessment of some water quality characteristics and determination of some heavy metals in lake Manzala, Egypt. Egypt. J. Aquat. Biol. and Fish., 12(2):133-154.

Bahnasawy, M.; Khidr, A. and Dheina, N. (2011). Assessment of Heavy Metal Concentrations in Water, Plankton, and Fish of Lake Manzala, Egypt. Turkish Journal of Zoology, 35: 271-280.

Barakat, M.A. (2011). New trends in removing heavy metals from industrial wastewater. Arab. J. Chem., 4: 361-377.

Dar, M.A.; Uosif, M. A.; Mohamadeen, L. I.; El Saharty, A. A.; Hamed, H. M. and Murad, F.A. (2015). The semi-annual variations of the bio-available heavy metals and natural radionuclides in Timsah Lake sediments, Egypt. International Journal of Scientific and Engineering Research, 6(5):2015-1697.

Dewidar, K.H. and Khedr, A. (2001). Water quality assessment with simultaneous Landsat-5 TM at Manzala Lagoon, Egypt. Hydrobiologia 457: 49-58.

Donia, N. and Hussein, M. (2004). Eutrophication assessment of lake Manzala using GIS techniques. Eighth International Water Technology Conference, IWTC 2004, Alexandria, Egypt.

Dowidar, A.A. and Hamza, R.W. (1983). Primary productivity and biomass of Lake Manzala. Rapp. Comm. Int. Mer. Medit., 28: 6-12.

El-Badry, A.E.A. (2016). Distribution of Heavy Metals in Contaminated Water and Bottom Deposits of Manzala Lake, Egypt. J Environ Anal Toxicol., 6: 344.

El-Bokhty, E.E.B. (1996). Distribution of bottom fauna in Lake Manzalah in relation to prevailing environmental conditions. M. Sc. Thesis, Fac. Sci. Tanta Univ., Egypt, 124pp.

El-Enany, H.R. (2004). Ecological and biological studies on Lake El-Manzalah with special reference to their water quality and sediment productivity. M.Sc. Thesis, Fac. Sci., Al Azhar Univ., 358 pp.

Elewa, A.A.; Saad, E.A.; Shehata, M.B. and Ghallab, M.H. (2007). Studies on the effect of drain effluents on the water quality of Lake Manzala, Egypt. J. Aquat. Biol. and Fish., 11(2): 65-78.

El-Ghobashy, A.E. (1990). Biological studies on the Western region of Lake Manzalah Ph.D. Thesis. Fac. Sci. Mans. Univ. 279 pp.

El-Naggar, N.A.; Rifaat, A.E. and Khalil, M. Kh. (2016). Numerical Modelling On Water Flow In Manzala Lake, Nile Delta, Northern Egypt. International Journal of Contemporary Applied Sciences, 3(4):28-44.

El-Refaie, Gh. (2010). Temperature impact on operation and performance of Lake Manzala Engineered Wetland, Egypt. Ain Shams Engineering Journal, 1: 1-9.

El-Sabrouti, M.A. and Mahmoud, B. (1990). Texture, Chemistry and mineralogy of Lake Manzalah sediments, Egypt. Rapp. Comm. Int. Mer. Medit. 33: 129.

El-Saharty, A.A. (2014). Seasonal Variation of Water Physicochemical Parameters and Trace Metals in Lake Manzala, Egypt. JKAU: Mar. Sci., 25(1): 37-58.

El-Sayed, S.M.M. (2011). Physicochemical studies on the impact of pollution up on the Nile River branches, Egypt. M.Sc. Thesis Faculty of Science, Benha University, Egypt. 
EL-Shafei, H.M. (2016). Assessment of some water quality characteristics as guide lines for the management of pond fish culture in Lake Manzala, Egypt. International Journal of Fisheries and Aquatic Studies, 4(2): 416-420.

El-Wakeel, S.K. and Wahby, S.D. (1970). Bottom sediments of Lake Manzalah, Egypt. J. Sed. Petrol., 40: 480-496.

Fathi, A.A. and Abdelzahar, H.M.A. (2003). Limnological studies on the wetland Lake El-Manzala, Egypt. Bull. Fac. Sci. Assiut. Univ., 32(2-D): 215-233.

Fathi, A.A.; Abdelzahar, H.M.A.; Flower, R.J.; Ramdani, M. and Kraiem, M. (2001). Phytoplankton communities in North African wetland Lakes: the CASSARINA Project. Aquatic Ecology, 35 (3-4): 303-318.

Flower, R.J. (2001). Change, stress, sustainability and aquatic ecosystem resilience in North African wetland lakes during the 20th century: an introduction to integrated biodiversity studies within the CASSARINA Project. Aquatic Ecology, 35(3-4): 261-280.

Frihy, O.; Dewidar K.; Nasr S. and El Raey, M. (1998). Change detection of the northern Nile delta of Egypt: shoreline changes, Spit evolution, margin changes of Manzalah lagoon and its islands. Int. J. Remote Sensing 19: 1901-1912.

Gad, N.S. (2005). Impact of environmental pollution in the southern region of Lake Manzalah Egypt on some biochemical parameters of Tilapia zillii, J. Egypt Ger. Soc. Zool. comparative physiology. 48(A): 279- 298.

Ghallab, M.H.M. (2000). Some physical and chemical changes on Nile River downstream of Delta Barrage at El-Rahawy drain. M. Sc. Thesis, Fac. of Sci. Ain Shams Univ. Cairo, Egypt.

Goher, M.E.M. (1998). Factors affecting the precipitation and dissolution of some chemical elements in Nile River at Damietta Branch. M. Sci. Thesis, Fac. of Sci. Menofiya Univ. Egypt.

Hamed, Y.A.; Abdelmoneim, T.S.; ElKiki, M.H.; Hassan, M.A. and Berndtsson, R. (2013). Assessment of Heavy Metals Pollution and Microbial Contamination in Water, Sediments and Fish of Lake Manzala, Egypt. Life Sci. J., 10: 86-99.

Hossen, H. and Negm, A. (2016). Performance of Water Bodies Extraction Techniques 'Embedded In Erdas': Case Study Manzala Lake, Northeast Of Nile Delta, Egypt. Nineteenth International Water Technology Conference, IWTC19 Sharm ElSheikh, 21-23 April 201650.

Hussein, K.A. (1997). Environmental Studies of Lake Manzala, Geological and Environmental Aspect of Coastal Region. p: 9.

Khalil, M.T. and El-Awamri A.A. (1988). Plankton organisms as bio indicators for organic pollution at the southern area (El-Genka) of lake Manzala, Egypt. The First National Conference on Environmental Studies and Research- June 1988 Cairo, Egypt.

Khalil, M.T. (1990). The physical and chemical environment of Lake Manzala, Egypt. Journal of Hydrobiologia, 196:193 - 199.

Khalil, M.T. and Bayoumi, A.R. (1988). Fishery assessment survey of Lake Manzala, Egypt, Bull. Nat. Inst. Oceanogr. and Fish., ARE, 14(3): 139-154.

Lotfy, I.M.H. (2001). Geochemical studies on recent sediments of Manzala Lake, Egypt. J. Egypt. German. Soc. Zool., 34: 57-76.

Lotfy, I.M.H. (2007). Heavy metals in water and sediments of lake Manzala, Egypt. J. Aquat. Biol. and Fish., 11: 257-267.

Mabrouk, D.B.M. (2004). Aspects of Manzalah Lake pollution on Mugil species. $\mathrm{Ph}$. D. Thesis, Zool. Dep., Girl's College. Ain Shams Univ. 
Mahboob, S.; Al-Balawi, H.F.A.; Al-Misned, F.; Al-Quraishy, S. and Ahmad, Z. (2014). Tissue metal distribution and risk assessment for important fish species from Saudi Arabia. Bulletin of Environmental Contamination and Toxicology, 92: 61-66.

Maria Adelaide; Ruveado; Arno Hdeolivera; Gilles Revel; Guypinte; Sophie Aroult and Pierr Toulhoat. (2000). Study of water and sediment interaction in the Dasvelas River Berazil - major and trace elements., 26(2): 255 - 274.

Mehanna, S.F.; Shaker, I.M. and Farouk, A.E. (2014). Impacts of excessive fishing effort and heavy metals pollution on the Tilapia production from Lake Manzalah. 4th Conference of Central Laboratory for Aquacult. Rese., 57-74.

Misheloff, R. (2010). Integrated water resource management II. Feasibility of wastewater reuse. Washington, DC: International Resources Group; 2010.

Mustafa, M.M.; Badr, N.B.E.; Hussein, M.M.A.; Amer, A.A.M. and El-Ghazali, A.E.M. (2015). A Decision Support System for Total Phosphorus Management in Lake Manzala. Life Science Journal 2015; 12(11).

Nagpal, N.K. (2004). Technical Report, Water Quality Guidelines for Cobalt. Water Quality Standards British Columbia. Ministry of Water, Land and Air Protection, 6.

Nasr, M. and Moustafa, M. (2014). Performance evaluation of El-Agamy wastewater treatment plant-Egypt. In: 10th International Conference on the Role of Engineering towards a Better Environment; Alexandria, Egypt. 2014.

Nwabueze, A. and Oghenevwairhe, E. (2012). Heavy metal concentrations in the west African clam, Egeria radiata (Lammark, 1 804) from mciver market, warri, Nigeria. Int. J. Sci. Nature., 3 (2): 309-315.

Nwabunike, M.O. (2016). The Effects of Bioaccumulation of Heavy Metals on Fish Fin Over Two Years. Nwabunike, J. Fisheries Livest Prod., 4:2.

Orabi, O.H. and Osman, M.F. (2015). Evaluation of Some Pollution at Manzala Lagoon: Special Reference to Medical Importance of Mollusca in Egypt. J. Environ. Anal. Toxicol., 5: 31.1

Rasheed, M.El.A., (2011): Ecological Studies on Lake El-Manzalah With Special Reference To Their Water Quality And Sediment Productivity. M. Sc. Thesis, Fac. Sci., Al Azhar Univ. Egypt, 367pp.

Saad, M.A.H. (2003). Impact of diffuse pollution on the Socio-economic development opportunities in the coastal Nile Delta Lakes, Diffuse Pollution Conference Dublin 2003.

Saeed, S.M. and Shaker, I.M. (2008). Assessment of Heavy Metals Pollution in Water and Sediments and Their Effect on Oreochromis niloticus in the Northern Delta Lakes, Egypt. 8th International Symposium on Tilapia in Aquaculture, 475-490.

Said, M.A. (1992). Detailed variations in mean temperature and heat content of some Egyptian lakes. Bull. Nat. Inst. Ocean. and Fish., Egypt., 18: 11-23.

Sallam, G.A.H., and Elsayed, E.A. (2015). Estimating relations between temperature, relative humidity as independed variables and selected water quality parameters in Lake Manzala, Egypt. Ain Shams Engineering Journal.

Yacoub, A.M.; Siliem, T.A.; Kadry, S.M. and Mabrouk, D.B. (2005). Effect of drainage water on the chemical characteristics of Lake Manzalah waters, Egypt. J. Egypt. Acad. Soc. Environ. Develop., (D- Environmental Studies). 6(1): 133152.

Zahran, M.A.; El-Amier, Y.A.; Elnaggar, A.A.; Abd El-Azim, H. and El-Alfy, M.A. (2015). Assessment and Distribution of Heavy Metals Pollutants in Manzala Lake, Egypt. Journal of Geoscience and Environment Protection, 3: 107-122. 


\section{ARABIC SUMMARY}

$$
\begin{aligned}
& \text { دراسة بعض العناصر الثقيلة في مياه المنطقة الجنوبية لبحيرة المنزلة ـ مصر } \\
& \text { وائل حسين رشدي حجازي 1، محمد عبد الفتاح حامد2، محمد الصديق توفيق2، }
\end{aligned}
$$

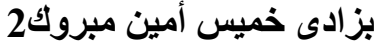

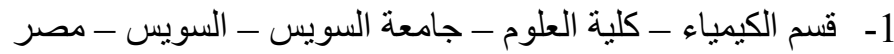

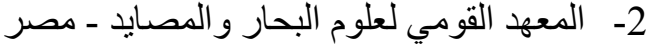

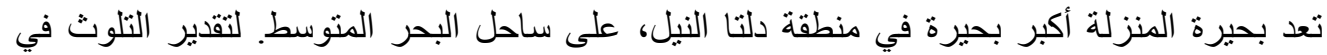

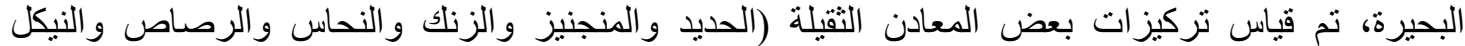

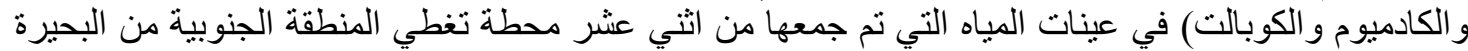

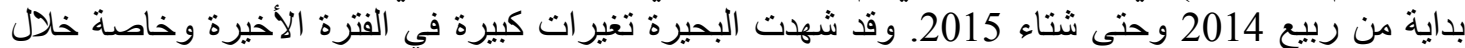

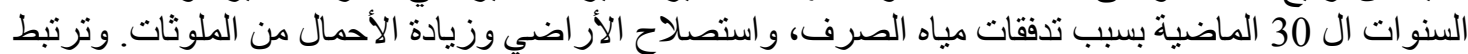

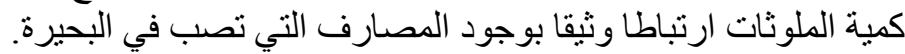

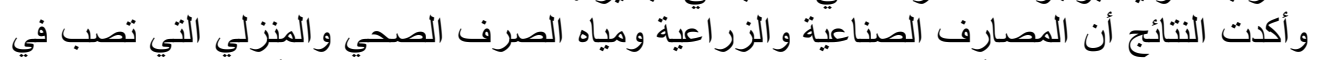

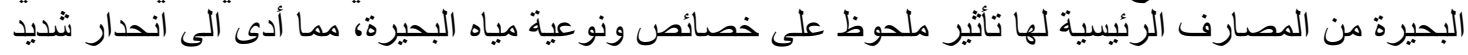
في جودة ونو عية المياه بالبحيرة.

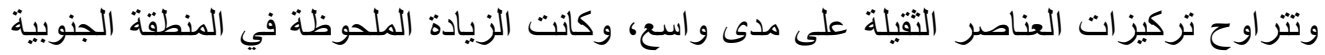
التي تصب فيها المصارف مباثرة، وتتخفض التركيزات كلما اتجهنا نحو الجزء الثمالي النياني الثرقي للبحيرة. 